\title{
13
}

\section{Engaging with government: A confessional tale}

\author{
Paul 't Hart
}

In the aloof and lofty heights of the political science program at the Research School of Social Sciences (RSSS) at The Australian National University (ANU) - we were a global 'top 10' department, I was told upon my arrival there in late 2005 - John Wanna was really the only one among my new colleagues who had a serious commitment to working with and for government. His research agenda and his editorial efforts at the Australian Journal of Public Administration, in running the ANZSOG book series at UNSW Press and later ANU E Press, were in no small measure shaped by what he knew was topical in political and administrative practice. He published self-consciously for the local market and maintained an active presence in the broadsheet and electronic media. The more academically snobbish colleagues at RSSS, of which there were plenty, were very disparaging for that very reason. I thought they were mad.

After a year's worth of the allegedly blissful, monk-like 'research-only' existence (meaning: no need for teaching or external engagements) while working on the kind of 'A-list' journal articles and weighty academic monographs that my colleagues appeared to regard as the be-all and endall of life as a political scientist, I found myself bored stiff. I mean, I enjoy doing research as much as the next academic, but to be mimicking my RSSS colleagues and do it ad infinitum - there was no retirement age that I could see - from the stuffy confines of the claustrophobic Coombs building with my door closed to the world outside, did feel like stretching 
it. I had had my professional socialisation in the Netherlands, where public administration is a standalone social science discipline rather than, as was the case in Australia, a condescendingly tolerated little pocket within the majestic realm of political science.

Working in that discipline, I had seen my mentors define its role as one of producing and communicating 'usable knowledge' (Cohen and Lindblom 1979). At the tender age of 20 , as a research assistant, I got to follow my boss, Professor Uriel Rosenthal, around to ministry boardrooms, invitation-only seminars and hands-on field work of observing decisionmaking during crises in real time. We studied how governments prepare for and respond to disasters, riots, acts of terrorism and other major disturbances in an otherwise stable and prosperous polity. At 26, I found myself lecturing to police, fire and military commanders in Holland and, inconceivably yet fortuitously, Australia. It seems a daunting thing to do now but of course back then I didn't think twice about it. When the European Cup final of 1985 in Brussels turned into a horrific crowd disaster, I went out with a colleague to reconstruct what had happened and used it to write a book in which we adapted and applied academic theories of disaster causation and crisis management to explain the course of events, which then informed years of executive teaching on such matters. When a 747 crashed into a multicultural suburb in Amsterdam, we observed and evaluated the city's response and published widely about what we had learned in academic settings.

And so, through many other ventures and experiences - some hard and humbling ones included - I had learned to take pride in combining the traditional academic pursuits with making an active contribution to the professional development of public servants, to public debate about government and politics and to the design and evaluation of public policies and programs. It's what you did, and it was appreciated by one's academic peers as well as by practitioner constituencies (even though the latter may not have always felt comfortable about what we had to say). And it was all based on a firm academic ethos of robust research and mental independence from the powers that be.

Mysteriously, to me at least, none this of appeared to be valued in my new surroundings. It was perhaps not actively despised, it was simply not contemplated as a viable way of being a 'political scientist'. Did I not realise that I had landed in a researcher's version of heaven with my 'research-only' appointment? Why would I bother with engagement with 
practice when the opportunity was there to do nothing other than churn out Oxford University Press books and articles for revered periodicals such as the American Political Science Review? Engaging with practitioners was left to the likes of the Crawford School, which was always spoken about as if it was a bit of a lower life form at the university. I have never been able to quite make up my mind whether it was intellectual conviction that was driving this stance, ideological dislike of government or simply a convenient cover for utter introversion. I should add that the guy who had appointed me, Rod Rhodes, was the only one with what I regarded was an acceptable excuse for what I considered to be the deplorable aloofness of my colleagues: he had 'been there and done it' over a long career in the UK that had involved extensive engagement with government. He had come to Australia to now single-mindedly focus on harvesting all he had learned in the process. He had earned his stance, and he became a close collaborator (and friend) from whom I have learned an awful lot.

Of all the others, Wanna was the exception who confirmed the rule, and perennially risked their derision for it. Unsurprisingly, considering the fact that he occupied the Sir John Bunting Chair in Public Administration funded by the Australia and New Zealand School of Government (ANZSOG), a joint venture of governments and universities entirely devoted to active engagement on the academia-practice interface, it was Wanna who gave me the golden tip that would rid me of my predicament. He told me to get in touch with Allan Fels, the then ANZSOG dean, to explore the possibilities of doing some executive education teaching for them. As one who had been present at the creation of the Netherlands School of Administration (in 1989), which had a similar mission and comparable structure to ANZSOG, it was music to my ears.

I met Fels at the ANZSOG annual conference. I was lucky in two ways. I had presented myself to him as an expert in public leadership, and it turned out ANZSOG had a vacancy for the leadership course in its Executive Master of Public Administration. And Fels was courageous enough to consider a 'nobody from Holland' for the spot - though I remember him asking me in his seemingly casual, almost offhand way to 'remind me again why it is that I should land you this role'. I must have thought of something, because he gave me the opportunity. It made me feel relevant again. It was at that same conference that I saw Peter Shergold, as secretary of the Department of Prime Minister and Cabinet, the then head of the Australian Public Service, making an impassioned speech - which included forceful and repeated banging of the rostrum - 
exhorting his colleagues in the audience to get on with the job to 'deliver, deliver, deliver'. It felt like coming home. These were the settings, the people, the discourses and the stakes that I had lived and breathed in Holland. It emboldened me to bring the world of 'Canberra' back to that of RSSS in other ways. I started organising 'policy breakfasts' where key ANU academics strutted their stuff for large and captivated public service audiences, and - importantly - vice versa.

Teaching at ANZSOG was - and still is - a privilege. I returned to live in Holland in 2011, but I still make the big trek twice a year (at least) to deliver several courses, lectures and events for ANZSOG. I have written and commissioned case studies - with Wanna - for its John L Alford case library, a brilliant, open access asset for giving a hands-on empirical grounding to teaching the art and craft of public policy, public management, leadership, collaboration, evaluation and the like. And it has inspired me to finally write that textbook on public sector leadership I had been procrastinating on for years on end.

May 2018. I co-chair a workshop on Successful Public Policy in Melbourne. Esteemed academics and 'pracademics' from around Australia and New Zealand present case studies of government policies, programs and reforms that have done well and have 'created public value', as the Harvard guru of engaged public administration scholarship Mark Moore would have it. The vibe is great. The scholars present talk about how it was almost a relief to be invited to write about the 'upside' of government, as so much of their energy - and incentive structure - appears to gravitate towards naming and explaining its challenges, dilemmas, paradoxes and failures. There should be a place for both, we all agree. At the margins of the sessions I chat with one of the smartest people in the room. He asks me about my whereabouts. I feed him my enthusiasm for the ANZSOG work, and the remarkable keenness to learn, share and reflect that I meet among the Australian and New Zealand practitioners that I teach there. I tell him it's not quite so in some other countries where I do similar work. He stares at me in amazement. Why would a guy like you spend so much time doing that, he wonders. 'I am lucky', he says, 'I don't have to do all that. I have a research-only appointment ...'

The moral of the story? There's two. First: let it be a matter of record that John Wanna has been a trailblazer for engaged, grounded, policy-relevant scholarship in Australia, carving out against the odds a path in a landscape that - at least at ANU at the time - was disturbingly barren. And he 
has accomplished this in his own way (a, well, idiosyncratic, endearing and occasionally enraging fashion, as all who have had experience with his unique correspondence habits will be able to testify) and on his own terms. Second: in the highly competitive institutional environment of modern academia, where publishing in highly specialised and mostly American and British journals that maintain 95 per cent rejection rates and charge authors for the privilege of sharing their own published output forms the backbone of its economy of esteem (and its economy of 'dough', I should add), it clearly takes continued determination and vigilance to persuade academics to allocate their time and energy to ill-understood and ill-appreciated activities such as applied research, executive education, and the somehow denigrating act of engaging with 'government'.

\section{References}

Lindblom, C. E. and D. K. Cohen. 1979. Usable Knowledge: Social Science and Social Problem Solving. New Haven: Yale University Press. 
This text is taken from Politics, Policy and Public Administration in Theory and Practice: Essays in Honour of Professor John Wanna, edited by Andrew Podger, Michael de Percy and Sam Vincent, published 2021 by ANU Press, The Australian National University, Canberra, Australia.

doi.org/10.22459/PPPATP.2021.13 